\title{
Effect of salinity on photosynthetic and enzymatic activities and tuberization yield in the genotype of potato cultivar Agria under in vitro conditions
}

\author{
Seyyed Nosrat Mousavi ${ }^{1}$, Mostafa Ebadi ${ }^{*}$, Mahdi Khorshidi ${ }^{2}$, Hossein Hokmabadi², Nahid \\ Masoudian' \\ ${ }^{1}$ Department of Biology, Damghan Branch, Islamic Azad University, Damghan, Iran. E-mail: Drsnmmusavi@gmail.com, \\ mtf.ebadi@gmail.com, nahidmasoudian@yahoo.com
}

${ }^{2}$ Department of Biology, University of Damghan, Iran. E-mail: mahdi.khorshidi@gmail.com, h.hokmabadi.11@gmail.com

* corresponding author

Received: 21/10/2019; Accepted: 03/04/2020.

\begin{abstract}
The aim of this study aimed to investigate the effect of salinity levels on physiological and biochemical properties and tuberization yield of potato, cultivar Agria, in MS culture medium. After preparation and cultivation of tuber, the lateral aerial buds were removed after a few months and cultured in MS medium. After that, healthy samples were prepared and induced at the above-mentioned salinity stress level and transferred to the culture medium. Two weeks later, an air sample was taken, and the physiological and biochemical properties studied in this study (photosynthetic pigments, proline, soluble sugars, anthocyanins, phenolic compounds, and the activity of some antioxidant enzymes) were measured. Finally, salinity stress assessment was evaluated and studied in a fluid environment. The effects of stress on different stages of seedling growth in vitro conditions and the activity of photosynthetic and enzymatic pigments were investigated using spectrophotometric measurements and in accordance with their protocols. Data analysis of variance showed that salinity reduces photosynthetic pigments and salinity to a concentration of $50 \mathrm{mM}$, it is resistant to the addition of compounds such as soluble sugars, proline and antioxidant activity but at higher concentrations (75 and $100 \mathrm{mM})$, the plant is likely to be severely damaged due to excessive growth in active oxygen species. Therefore, due to the increase in antioxidant activity, it indicates an increase in the removal of active oxygen species, this feature is often used as an indicator to increase salinity tolerance. Research on the different ecological conditions in Iran, research is needed on other potato cultivars and molecular studies.
\end{abstract}

Keywords: Solanum tuberosum, tissue culture, salinity stress, antioxidant enzymes.

\section{Efeito da salinidade nas atividades fotossintéticas e enzimáticas e no rendimento da tuberização no genótipo da cultivar de batata Agria sob condições in vitro}

\section{RESUMO}

O objetivo deste trabalho foi investigar o efeito dos níveis de salinidade nas propriedades fisiológicas, bioquímicas e na produtividade da tuberização da batata, cultivar Agria, em meio de cultura MS. Após preparação e cultivo do tubérculo, os botões aéreos laterais foram removidos após alguns meses e cultivados em meio de cultura MS. Em seguida, amostras saudáveis foram preparadas e induzidas no nível de estresse salino mencionado acima e transferidas para o meio de cultura. Duas semanas depois, uma amostra de ar foi coletada e as propriedades fisiológicas e bioquímicas analisadas neste estudo (pigmentos fotossintéticos, prolina, açúcares solúveis, antocianinas, compostos fenólicos e a atividade de algumas enzimas antioxidantes) foram medidas. Por fim, a avaliação do estresse salino foi realizada e estudada em um ambiente fluido. Os efeitos do estresse sobre os diferentes estágios de crescimento de plântulas em condições in vitro e sobre a atividade de pigmentos fotossintéticos e enzimáticos foram investigados por meio de medidas espectrofotométricas e de acordo com seus protocolos. A análise de variância dos dados mostrou que a salinidade reduz os pigmentos fotossintéticos; e a salinidade a uma concentração de $50 \mathrm{mM}$ é resistente à adição de compostos como açúcares solúveis, prolina e atividade antioxidante, mas em concentrações mais altas (75 e $100 \mathrm{mM})$, é provável que a planta seja severamente danificada devido ao crescimento excessivo de espécies ativas do oxigênio. Portanto, devido ao aumento da atividade antioxidante, a qual indica um aumento na remoção de espécies ativas do oxigênio, esse recurso é frequentemente usado como um indicador para aumentar a tolerância à salinidade. Devido às diferentes condições ecológicas do Irã, pesquisas adicionais são necessárias em outras cultivares de batata e estudos moleculares.

Palavras-chave: Solanum tuberosum, cultura de tecidos, estresse salino, enzimas antioxidantes. 


\section{Introduction}

The Potato (Solanum tuberosum L.) is one of the 2000 species of the Solanaceae family and plants such as tobacco, tomato, eggplant and pepper (Hipskind et al., 1996). Potato is the fourth most important crop in the world after wheat, rice and maize and In Iran, it has occupied the second place in production after wheat (Christie et al., 1994).

The area under cultivation of potatoes across the country of Iran has been estimated to be about 162,700 hectares, of which $96.7 \%$ are lands under water culture and $3.3 \%$ are lands under rain-fed culture (dryland farming) and the production of this crop in the country is equal to $3,430,407 \mathrm{t}$. Since two tons of seed tubers are needed per hectare, 325,000 tons of seed tubers are required annually, most of which are imported from the producing countries (Arab Ahmadi et al., 2014).

Growth and production of plant products have always been influenced by different environmental conditions, such as drought, salinity, lack of food balance and improper temperature. The effects of salinity can be briefly interpreted in three main sections, including decreased water in the tissue, ion imbalance and ion toxicity. Salinity-induced growth decrease or stoppage is directly related to total soluble salt concentration or soil water osmotic potential (Khorshidi Benam et al., 2002).

Chlorophyll in the leaves is damaged by salinity stress, resulting in reduced photosynthesis. Hung and Redman (1995) have also referred to decreased amount of total chlorophyll content of barley leaves under salinity stress. Sodium and chlorine ions are usually the most common ions in saline soils and waters and both of them can have harmful effects on plants because with increased osmotic pressure of the soil solution, they disturb the equilibrium of the ions needed by the plant such as potassium while creating ionic toxicity in the plant (Koca et al., 2007).

About 300 disease and pest agents have been recognized in this plant, whose transmission through infected tubers to the next generation can reduce the product even by $90 \%$. Seedlings and tubers free of pathogens in potato produced through tissue culture can be used as one of the best methods in certified seed production plans (Shahbazi, 2015).

The use of multi-meristem culture for potato cell proliferation method, by shoot apex culture and use of a shaker, allows of bud proliferation. From the shoot apex explants, adventitious lateral buds grow, which together form a multi-meristematic mass. In this method, lateral buds or single nodes in MS medium containing 0.5 mg/l-1BAP, $0.5 \mathrm{mg} / \mathrm{l}-1 \mathrm{GA} 3,0.03$ sucrose, $2 \mathrm{mg} / \mathrm{l}-1$ calcium pantothenate and $0.7 \%$ agar were grown in 16 hours of light. Then, the explants were transferred to the medium containing the same hormone concentration plus $0.01 \mathrm{mg} / \mathrm{l}-1 \mathrm{NAA}$. These culture media were placed on a shaker at $90 \mathrm{rpm}$. The shoots obtained at this stage can be transferred to the soil after three weeks (Movahhedi Dehnavi, 2017). Were reported microtuberization during the 12-hour photoperiod (Mollassiotis et al., 2006).

The tuberization in two potato cultivars, Draga and Agria, using the apical meristem culture method, allowed to check that in cultivar Agria, the average weight of micro-tubers is greater than that of cultivar Draga, being the temperature suitable for tuberization of 18-19 C (Arab Ahmadi et al., 2014).

With potato meristem culture on MS medium, has been confirmed that a major part of amidone seeds accumulate in the skin parenchyma and development of vacuole is in brain parenchyma cells, which have high dimensions compared to skin parenchymal cells (Ebadi et al., 2011).

In work with potato meristem culture on MS medium it was possible to confirm that the bulking of micro-tubers, at the beginning, is caused by the alterations in the dimensions of the skin and brain parenchyma cells resulting from proliferative activity of apical meristem and also proliferative activity in the skin and brain parenchyma. Was observed that increased salt minerals reduce the number of microtubers. Was also verified that salt minerals at high concentrations decrease micro-tuber dry weight (Ebadi et al., 2011). Salinity does not directly affect the plant, but some metabolites called secondary messengers are involved in the internal signal transmission. One of these important molecules is inositol triphosphate, which affects and activates a protein in the endoplasmic reticulum membrane called calcium-permethase (Daneshmand et al., 2011).

Considering the importance of potato cultivar Agria, that has incresead the cultivationin Semnan Province, especially in Shahroud, due to desirable yield and marketability. Since salinity is considered a limiting factor, the effect of salinity on physiological properties and photosynthetic materials and other enzymes was evaluated and the impact of salinity levels on tuberization in in vitro culture medium was measured and analyzed. Hence, this study aimed to investigate the effect of salinity levels on physiological and biochemical properties and tuberization yield of potato, cultivar Agria, in MS culture medium.

\section{Material and Methods}

To investigate the response of one type of potato genotypes to salinity stress under in vitro conditions for measuring some physiological and biochemical traits, an experiment was carried out in one of the biology laboratories of Damghan University in the form of a 
completely randomized design with three replications. The main factor was a potato cultivar called Agria and subsidiary factors included 5 levels of salinity stress $(0$, $0.25,0.50,0.75$ and $100 \mathrm{mM} \mathrm{NaCl}$ ). Physiological and biochemical responses of samples in different salinity stresses and finally the importance of tuber and tuberization in this plant in salinity stress were evaluated. To sample in this experiment, healthy potato seed tubers were initially prepared in spring 2016 and were planted in yonolit pots filled with ordinary agricultural soil. After about three months, single nodes were prepared from the aerial shoots of the planted tubers and were cultured in in vitro media in order to obtain sterile seedlings.

For sterilization, single nodes obtained from the aerial stems of potato that are cultured as seeds in the first stage in solid MS medium were initially sterilized in terms of the presence of microbes, fungi, etc. The sterilization steps were washed with water and a dilute mixture of water and a detergent (Twin), $70 \%$ alcohol and $1 \%$ mercury chloride, and dust and excessive matters were removed from them and they were then put in sterile media (Arab Ahmadi et al., 2014).

Most plant species require different culture media. MS medium is the best medium used for plant tissue culture. Thus, selection of the best medium is accompanied by problems (Gao et al., 1998).

Mother solutions were prepared from high and low consumption mineral salts and vitamins and iron in varying amounts and were dissolved in $100 \mathrm{mM}$ distilled water. These mother solutions were stored in the refrigerator. Moreover, in this research, hormonal solutions were made based on $1 \mathrm{mg} / \mathrm{lit}-1$ hormone. To make hormone solutions for induction based on 1 $\mathrm{mg} / \mathrm{lit}-1$ hormone, we dissolved $0.1 \mathrm{~g}$ of the desired hormone powder in $100 \mathrm{~m}$ of water and obtained 1 $\mathrm{mg} / \mathrm{lit}$ hormone by taking $10 \mathrm{cc}$ of this solution and bringing the solution to a volume of one liter (Gao et al., 1998).

According to the induction table below, we have:

Table 1. Mineral salts and vitamins and iron in varying amounts

\begin{tabular}{cccc}
\hline Hormone & $\begin{array}{c}\text { Sterile } \\
\text { seedling }\end{array}$ & $\begin{array}{c}\text { Shoot } \\
\text { formation }\end{array}$ & $\begin{array}{c}\text { Tuberization } \\
\text { induction }\end{array}$ \\
\hline NAA & $0 / 1 \mathrm{mgl}-1$ & 0 & 0 \\
GA3 & $5 / 0 \mathrm{mgl}-1$ & $0 / 4 \mathrm{mgl}-1$ & 0 \\
BAP & 0 & $0 / 5 \mathrm{mgl}-1$ & 10 mglit-1 \\
\hline
\end{tabular}

Next, to make 1 liter of MS medium, we took 100 $\mathrm{ml}$ from mother solution of high-consumption compounds, $10 \mathrm{ml}$ from mother solution of lowconsumption compounds, $10 \mathrm{ml}$ from mother solution of vitamins and $10 \mathrm{ml}$ from mother solution Fe-NaEDTA and added $30 \mathrm{~g}$ of sucrose to them. By adding the needed hormones and bringing the solution to the required volume, solution $\mathrm{pH}$ was adjusted to 5.6. To prepare solid medium, $8 \mathrm{~g}$ of agar was added. After dissolving agar with heat accompanied by stirring (using magnetic stirrer), the culture solution was finally sterilized at $121^{\circ} \mathrm{C}$ (moist heat) at a pressure of 1.5 $\mathrm{kg} / \mathrm{cm}^{-2}$ for 20 minutes. These media were used for study after cooling and distributing. In order to induce micro-tuberization, aerial stems and shoots are needed in the culture medium since the potato tuber consists of potato stems and stolons. Thus, it seems necessary to proliferate the sterile seedling shoots from the first stage. In this stage, after preparation of MS liquid medium (without agar) with hormones of $0.5 \mathrm{mg} / \mathrm{l} \mathrm{BAP}$ and $0.4 \mathrm{mg} / \mathrm{l} \mathrm{GA} 3$ and their distribution in $100 \mathrm{cc}$ and $250 \mathrm{cc}$ erlenmeyers, explants from shoots with 2 or 3 nodes from sterile seedlings were cultured in them in sterile medium and conditions and were placed on a shaker at $100 \mathrm{rpm}$ for two to four weeks. In the end, we obtained seedlings with multiple shoots within 3-4 weeks.

In order to induce micro-tuberization of multipleshoot seedlings in erlenmeyers of the previous stage (shoot proliferation) and prepare the plant materials needed for micro-tuber induction, MS media containing $10 \mathrm{mg} \mathrm{L}^{-1}$ hormone were put in Laminar Airflow device and then, the multiple-shoot seedlings of the previous stage were removed from the MS liquid medium and the above liquid media were added to the erlenmeyers as control nodes and were placed on a shaker under physical conditions (absolute darkness) and temperature of $20-22^{\circ} \mathrm{C}$ for $40-50$ days and their tuberization quality was examined. BAP and $80 \mathrm{~g} / \mathrm{l}$ sucrose were prepared for micro-tuberization. Afterwards, under sterile and proper physical conditions, different salt treatments were added to MS media for micro-tuberization according to its different concentrations and different results were obtained.

In this research, the concentration of chlorophyll a and chlorophyll $\mathrm{b}$, total chlorophyll and carotenoids, soluble sugar, proline, malondialdehyde (MDA) and others were measured using the spectrophotometric method and to measure the amount of hydrogen peroxide, potato leaves were initially homogenized in $0.1 \%$ trichloroacetic acid. The extract was centrifuged in refrigerated centrifuge at $10,000 \mathrm{~g}$ for 15 minutes. Then, $0.5 \mathrm{ml}$ of the supernatant was added to $0.5 \mathrm{ml}$ of $10 \mathrm{mM}$ potassium phosphate buffer $(\mathrm{pH}=7)$ and $1 \mathrm{ml}$ of $1 \mathrm{M}$ potassium iodide and the absorbance was read at $390 \mathrm{~nm}$. After that, to measure phenolic compounds, 0.1 $\mathrm{g}$ of the plant leaf was powdered in $5 \mathrm{ml}$ of $95 \%$ ethanol and was kept in the dark for 24 to 72 hours.

Afterwards, it was centrifuged at $4000 \mathrm{~g}$ for 5 minutes and $0.5 \mathrm{ml}$ of $95 \%$ ethanol was added to $0.5 \mathrm{~mL}$ of the supernatant and with distilled water, the solution 
volume reached $2.5 \mathrm{~mL}$. $0.25 \mathrm{~mL}$ of $50 \%$ Folin reagent and $0.5 \mathrm{ml}$ of $5 \%$ sodium carbonate were also added. The resulting mixture was kept in the dark for 1 hour and then, the absorbance of each sample was read at 725 nm. Ascorbate peroxidase activity was measured based on Chen and Asada (1989); Nakano and Asada (1981) method.

Ultimately, physiological and biochemical traits of potato seedlings, including chlorophyll a and chlorophyll $\mathrm{b}$ concentrations, total chlorophyll and carotenoids (consisting of carotene and xanthophylls), soluble Sugar, proline, malondialdehyde (MDA), hydrogen peroxide, phenolic compounds, protein, activity of enzymes (SOD, CAT, APX, GPX, GR).

For statistical analysis, a completely randomized design (for laboratory and greenhouse designs) with three replications was implemented and the statistical data were obtained and then, their analysis was made by SPSS software. To determine the mean difference of data, Duncan test was used at a $95 \%$ confidence level. Data have been presented as mean \pm standard error. Charts and graphs were plotted by Excel software.

\section{Results and Discussion}

\subsection{Photosynthetic pigment activity}

The analysis of variance revealed that salinity levels have a significant effect on photosynthetic pigments Figure 1 In general, the salinity has decreased the amount of chlorophyll a, chlorophyll b, total chlorophyll and carotenoids and with increased salinity from $0 \mathrm{mM}$ to $100 \mathrm{mM}$, the amount of the plant chlorophyll has had a downward trend so that the least chlorophyll content is related to a salinity concentration of $100 \mathrm{mM}$ and the greatest chlorophyll content is related to the control group.

In this study and with regard to the results and graphs extracted, it is found that salinity has reduced the amount of chlorophyll a, chlorophyll b, total chlorophyll and carotenoids and it seems that salinity has also affected chloroplasts, pigments and carotenoids in the plant sample and has decreased them. Consequently, these experiments are in line with the reports by (Khavarinejad and Chaparzadeh, 1998).

Arab Ahmadi et al. (2014) investigated the effect of salinity levels on the amount of chlorophyll a, chlorophyll $b$, total chlorophyll and carotenoids of the plant and reported that salinity levels reduce the amount of plant indicators. Was reported that the amount of total chlorophyll and carotenoids in tomato has decreased under salinity stress. Another reason is the decreased chlorophyll synthesis due to reduced absorption of ions such as $\mathrm{Fe}$ and $\mathrm{Mg}$ that play a fundamental role in the chloroplast structure and hence, by decreasing the absorption of these ions, chlorophyll synthesis decreases (Khavarinejad and Chaparzadeh, 1998).

In brief, it can be concluded that there is an inverse relationship between increased salinity and the chlorophyll content based on the four graphs extracted from this experiment and any increase in salinity will have deleterious effects on physiological properties and subsequently negative effects on morphological traits and yield components.
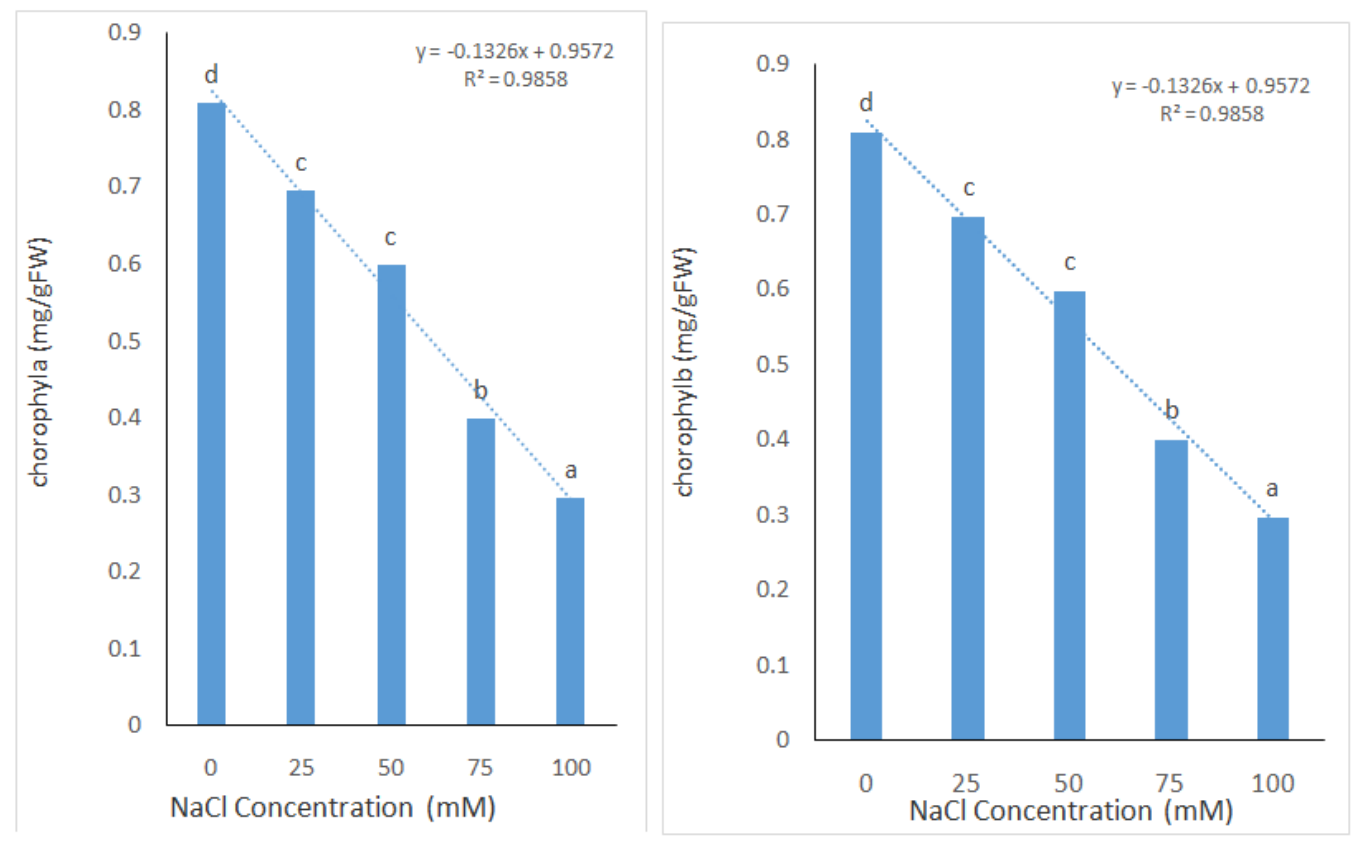

Revista de Agricultura Neotropical, Cassilândia-MS, v. 7, n. 3, p. 8-19, jul./set. 2020. 
12 Effect of salinity on photosynthetic and enzymatic activities and tuberization yield in the genotype of potato cultivar Agria...

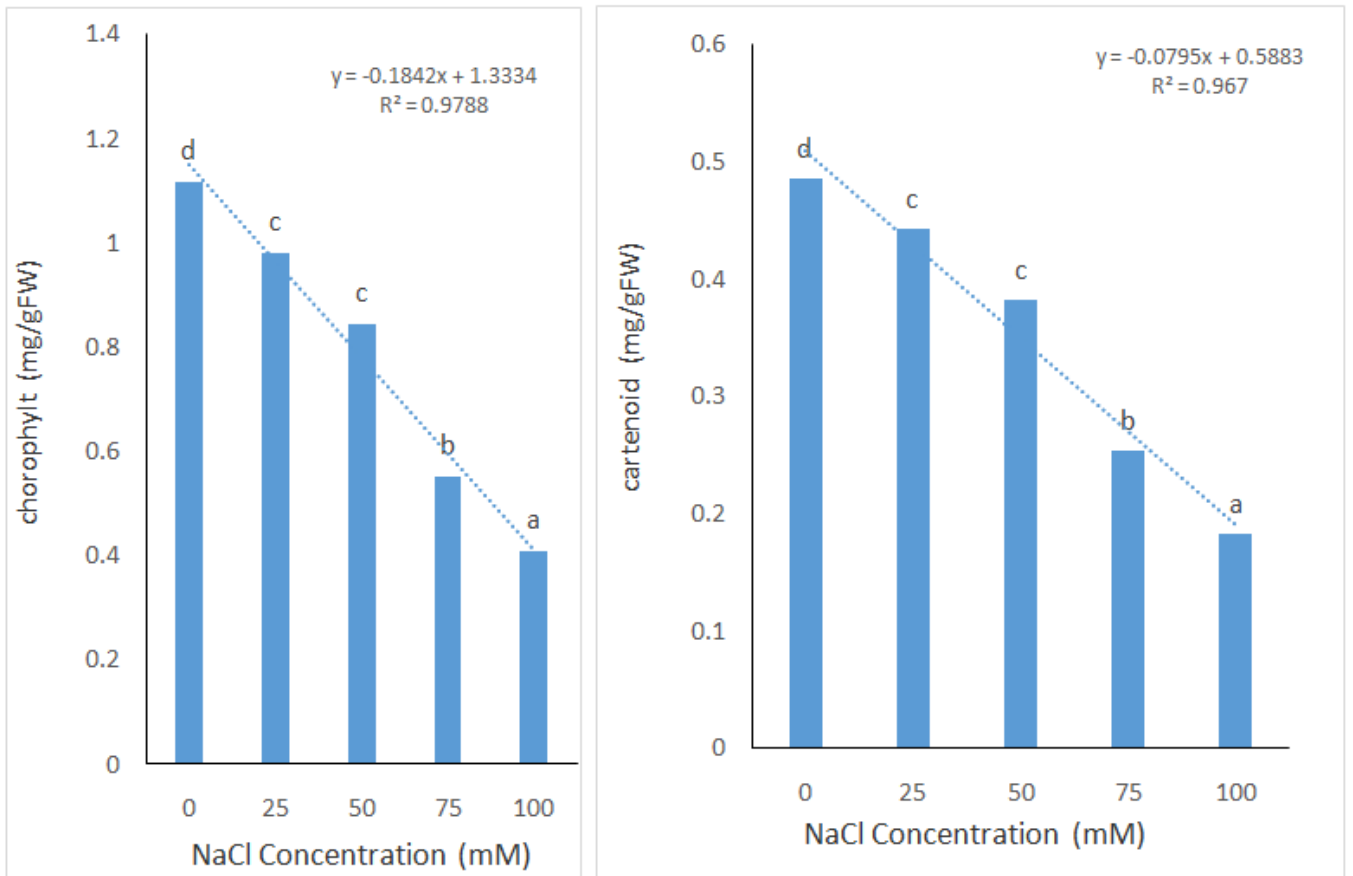

Figure 1. Effect of the interaction of salinity levels on physiological properties of potato cultivar Agria (chlorophyll a, chlorophyll b, total chlorophyll and carotenoid).

\subsection{Anthocyanin pigment activity}

The analysis of variance results indicate that salinity levels partially increase anthocyanin and then decrease it. The amount of anthocyanin obtained from the samples (Figure 2), displayed that as salinity increases from 0 to $50 \mathrm{mM}$, the amount of anthocyanin increases and it has an upward trend. But at 75 and $100 \mathrm{mM}$ concentrations, it has a downward trend. Therefore, the highest amount was observed in $50 \mathrm{mM}$ treatment and the lowest amount in $100 \mathrm{mM}$ treatment. Besides, a significant difference was found in the comparison of 25 and $50 \mathrm{mM}$ concentrations, but the concentration of 75 $\mathrm{mM}$ was not significantly different from the control group. Hipskind et al. (1996) reported that in some cases, at high salinity concentrations, the anthocyanin content is reduced compared to the control group. This reduction in anthocyanin content cannot be attributed to the low plant resistance to salinity because the plant may have used other mechanisms for its reinforcement. The studies conducted by them also illustrate that anthocyanins can act in harmony with the protective molecules in plant cells and take action to compensate for the defect in the concentration of molecules during the stress period. Anthocyanins act in special places inside the leaves for optimal plant efficiency (Hipskind et al., 1996). Many environmental stimuli such as ultraviolet radiation, low temperature, invasion of pathogens and several growth regulators including cytokinin, gibberellin, ethylene and salicylic acid induce anthocyanin accumulation. Accordingly, the experiments performed in this study are consistent with those of other researchers.

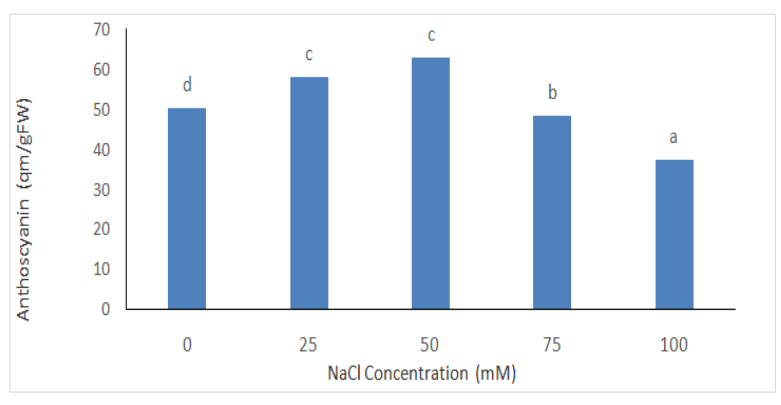

Figure 2. Effect of the interaction of salinity levels on physiological properties (anthocyanin).

\subsection{The effect of salinity on soluble sugar measurement activity}

The analysis of variance results about the effect of salinity on the activity of measuring the plant soluble sugars in this study showed that salinity at a $25 \%$ concentration has led to a slight increase in the amount of soluble sugars, but at higher concentrations, the soluble sugars gradually decreased and reached the lowest amount at a $100 \mathrm{mM}$ concentration (Figure 3). It seems that this decrease is consistent with other researchers' finding for the reasons presented below. Salinity stress changes the structure of sugars such as glucose, fructose, sucrose and fructans in a number of plants. Gao et al. (1998) reported that in tomato leaves, the amount of soluble sugar and total saccharides significantly increased in salinity treatment, but the amount of starch did not change significantly. Munns (2005) also stated that significant changes in osmotic potential are associated with changes in the amount of sugars. 


\subsection{The effect of salinity on proline activity}

The analysis of variance results at salinity levels suggested that as salinity increased, proline content also increased and had an upward trend and there was almost a direct linear relationship between increased salinity and increased proline content in salinity concentrations of 0 to $75 \mathrm{mM}$, their difference was significant (Figure 4). But at a concentration of $100 \mathrm{mM}$, a slight decrease was observed, which is not statistically significant. Thus, this laboratory assay is consistent with the studies of other researchers.

\subsection{The effect of salinity levels on malondialdehyde (MDA)}

The effect of salinity on malondialdehyde and other aldehydes demonstrated that salinity increased the concentration and amount of malondialdehyde and the highest amount was obtained at a 100 concentration and this amount had a downward trend toward the control group. Further, the difference between the salinity concentration of 25 and the control group and also 50 $\mathrm{mM}$ was not significant. But the other groups were significantly different (Figure 5). The lipid peroxidation decomposition reaction can produce peroxyl and alkoxy radicals in addition to hydroxyl purifiers. The amount of malondialdehyde during peroxidation of membrane lipids serves as an oxidative stress index. Reports of other researchers such as Zarghami (2009) concerning the sensitive rice cultivar and Indian sesame under salinity stress indicate increased malondialdehyde content. Additionally, the mentioned researchers

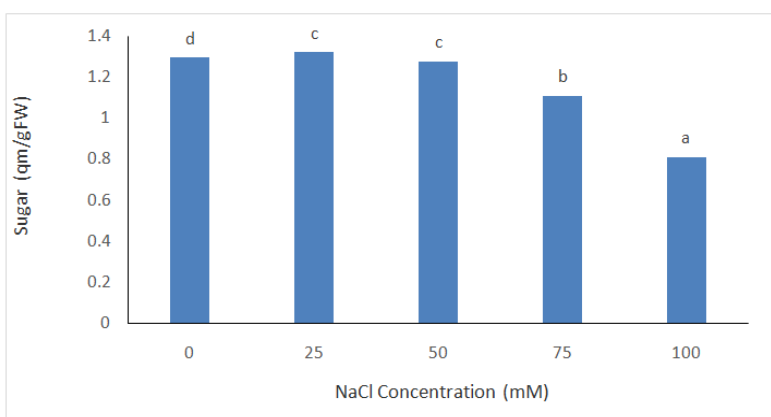

Figure 3. Effect of the interaction of salinity levels on physiological properties (soluble sugars).

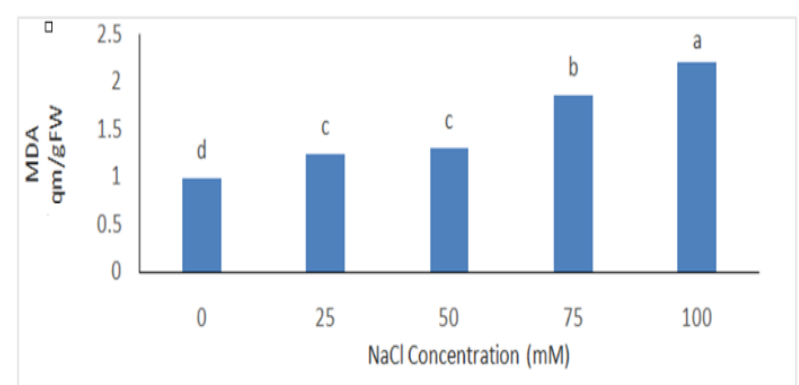

Figure 5. Effect of the interaction of salinity levels on physiological properties (MDA). reported that MDA content in the oat plant increased under salinity stress due to $\mathrm{H}_{2} \mathrm{O}_{2}$ accumulation, which is caused by the peroxidation of membrane lipids, compounds such as malondialdehyde, propanal, butanol, hexanal, heptanal and propanal dimethyl acetal.

\subsection{The effect of salinity levels on hydrogen peroxide}

The effect of salinity levels on hydrogen peroxide content revealed that the process of changes in hydrogen peroxide is similar to changes in other aldehydes. Accordingly, there were no significant differences between the three primary groups, i.e. control, $25 \mathrm{mM}$ and $50 \mathrm{mM}$. But a statistically significant difference was found at $75 \mathrm{mM}$ and $100 \mathrm{mM}$ levels. So, the highest amount of hydrogen peroxide was observed in $100 \mathrm{mM}$ and the lowest amount in the control group (Figure 6).

With increased salinity dose, the amount of hydrogen peroxide showed a significant increase from the control group to $100 \mathrm{mM}$. These results are consistent with other results described below. In the cucumber plant, the amount of hydrogen peroxide increased under salinity stress. $\mathrm{H}_{2} \mathrm{O}_{2}$ content in rice also increased hydrogen peroxide under cadmium stress. Hydrogen peroxide oxidized the Calvin cycle enzymes, such as glyceraldehyde dehydrogenase and fructose bisphosphatase, even at low concentrations and deactivated them. Salinity stress imposes dehydration on plant because osmosis affects a wide range of metabolic activities. This water deficit results in the formation of reactive oxygen species, such as superoxide and singlet oxygen.

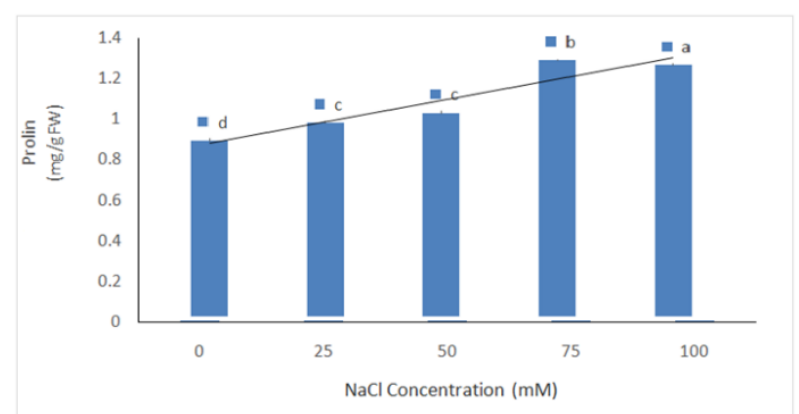

Figure 4. Effect of the interaction of salinity levels on physiological properties (proline).

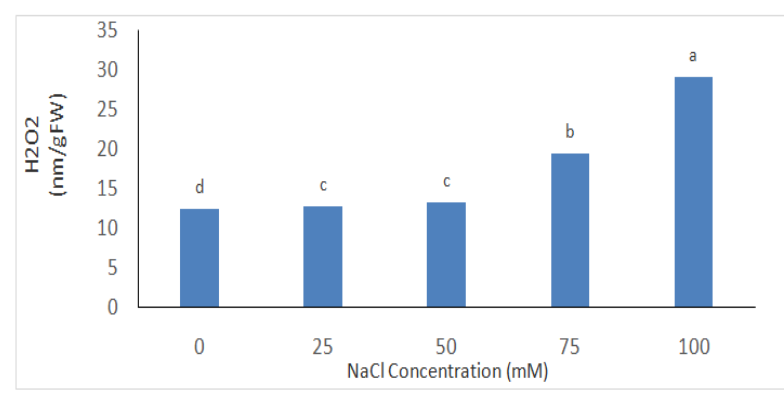

Figure 6. Effect of the interaction of salinity levels on physiological properties (hydrogen peroxide). 


\subsection{The effect of salinity levels on the measurement of phenolic compounds}

The phenolic compounds initially increased with increasing salinity concentration, but at salinity concentrations of 75 and $100 \mathrm{mM}$, the amount of phenolic compounds decreased. As a result, the difference between all groups was significant and the highest amount was observed at $50 \mathrm{mM}$ salinity and the lowest amount at $100 \mathrm{mM}$ salinity (Figure 7). Therefore, the data revealed that salinity stress has caused a significant decrease in the amount of phenolic compounds. These results are congruent with those of other researchers. Phenolic compounds are part of soluble substances of the cell that have a moderating effect during stress period. Besides, the accumulation of phenolic compounds in salt-tolerant plants is a strategy to inhibit the activity of active oxygen radicals and protect the membrane against salinity stress damage. Compounds such as coumarin, flavonoids, catechol and caffeic acid are considered as phenolic compounds (Mollassiotis et al., 2006).

\subsection{The effect of salinity levels on protein}

The analysis of variance results indicate that with increased salinity levels, the amount of protein decreases and there is an inverse relationship between salinity and plant protein. Consequently, the lowest amount of protein was observed in $100 \mathrm{mM}$ salinity and the highest amount in the control group (Figure 8). Although there is no statistically significant difference between $25 \mathrm{mM}$ salinity with the control group and 50 $\mathrm{mM}$ salinity, the difference between the other groups is significant. Thus, the results of this experiment are consistent with the results of other researchers as stated below.

In general, salts have two incompatible effects on proteins: 1) The tendency to break electrostatic bonds; 2) increased hydrophobic interactions. As to the salinity effect on strawberries, it has been reported that the soluble protein of this plant increases at low salinity and decreases at high salinity. Another report on the salinity effect on plant proteins suggests that the production of new proteins in this plant has been induced under salinity stress. It was demonstrated that under salinity stress, the amount of proteins in cassia plant increases, which is associated with increased synthesis of proteins such as HSP and LEAS. These proteins protect the plant against environmental stresses. These proteins produced under stress conditions act as chaperones and protect the enzymes and proteins in the cell. Chaperones are spherical molecules that prevent the accumulation of abnormal proteins and denaturation and condensation of proteins (Khavarinejad and Chaparzadeh, 1998).

\subsection{The effect of salinity levels on superoxide dismutase (SOD) enzyme activity}

The salinity up to $50 \mathrm{mM}$ has increased the activity of superoxide dismutase enzyme. The difference between all groups was statistically significant and the difference between $75 \mathrm{mM}$ concentration, control group and $25 \mathrm{mM}$ concentration was minor but not significant. At 75 and $100 \mathrm{mM}$ concentrations, the amount of superoxide dismutase enzyme activity decreased. As a result, the lowest activity was observed at $100 \mathrm{mM}$ salinity and the highest activity at $50 \mathrm{mM}$ salinity (Figure 9).

\subsection{The effect of salinity levels on catalase (CAT) enzyme activity}

The salinity increases its activity and that it has a relative and increasing trend up to a concentration of 75 $\mathrm{mM}$ (Figure 10). This experiment increased the catalase enzyme activity at salinity concentrations of 25 and 50 $\mathrm{mM}$.

Although 75 and $100 \mathrm{mM}$ salinity concentrations increased catalase activity compared to the control group, the enzyme activity decreased slightly in 100 $\mathrm{mM}$ salinity compared to $75 \mathrm{mM}$ and the difference between concentrations of 75 and $50 \mathrm{mM}$ and also between 25 and $100 \mathrm{mM}$ was not significant.

\subsection{The effect of salinity levels on guaiacol peroxidase (GPX) enzyme activity}

With increased salinity up to a concentration of 50 $\mathrm{mM}$, guaiacol peroxidase enzyme activity also increased and at 75 and $100 \mathrm{mM}$ salinity, the enzyme activity decreased.

In addition, the greatest activity of guaiacol peroxidase was observed at 25 and $50 \mathrm{mM}$ salinity and the least activity of this enzyme was at a concentration of $100 \mathrm{mM}$. Also, a significant difference was observed between $50 \mathrm{mM}$ salinity and the control group and other groups including 75 and $100 \mathrm{mM}$ (Figure 11).

\subsection{The effect of salinity levels on ascorbate peroxidase (APX) enzyme activity}

With increased salinity up to $50 \mathrm{mM}$, the APX enzyme activity also increased. But at higher concentrations, such as 75 and $100 \mathrm{mM}$, ascorbate peroxidase enzyme activity was reduced. Moreover, the highest activity of ascorbate peroxidase was observed in $50 \mathrm{mM}$ salinity and the lowest activity was in $100 \mathrm{mM}$ salinity. No significant difference was found between 25 $\mathrm{mM}$ salinity with the control group and $50 \mathrm{mM}$ salinity. Also, a minor, but not significant, difference was observed between of $75 \mathrm{mM}$ concentration and control group (Figure 12). 


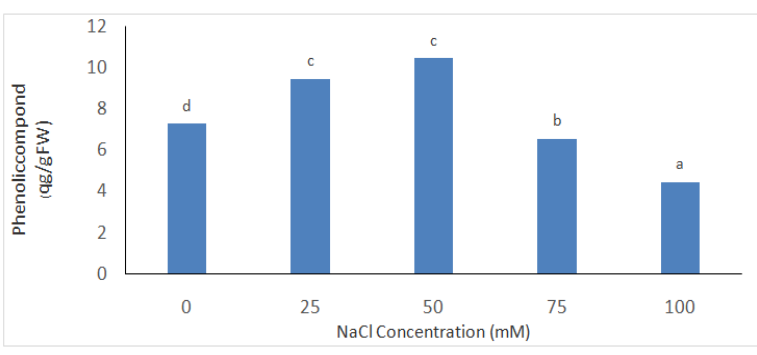

Figure 7. Effect of the interaction of salinity levels on physiological properties (phenol)

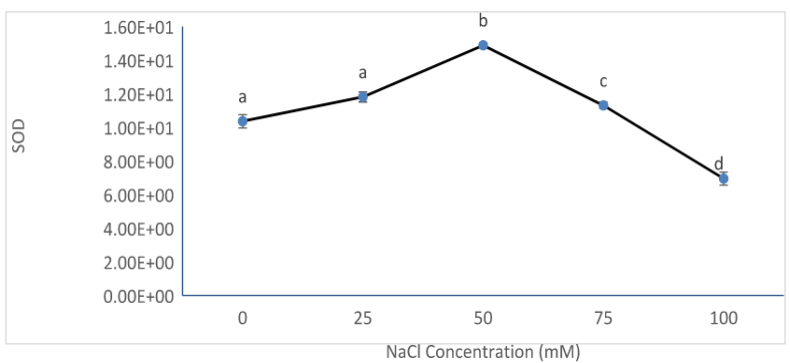

Figure 9. Effect of the interaction of salinity levels on physiological properties (SOD).

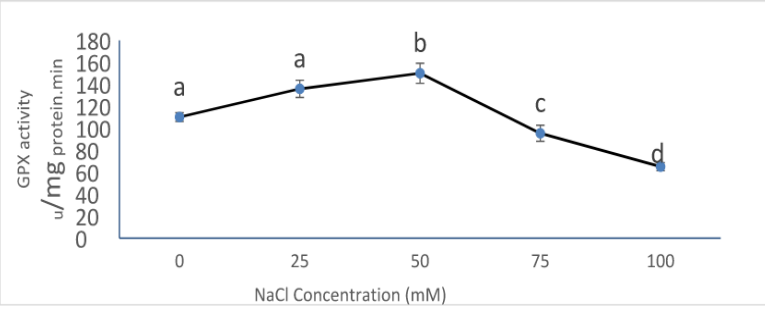

Figure 11. Effect of the interaction of salinity levels on physiological properties (GPX).

\subsection{The effect of salinity levels on glutathione reductase (GR) enzyme activity}

As salinity increases, glutathione reductase activity increases up to a concentration of $50 \mathrm{mM}$ and with increased salinity concentration at levels higher than 50 $\mathrm{mM}$, its activity decreased so that the lowest activity was observed at $100 \mathrm{mM}$ salinity and the highest activity was at $50 \mathrm{mM}$ salinity and there was a significant difference between the control group and other groups (Figure 13).

Koca et al. (2007) reported increased activity of superoxide dismutase, catalase and glutathione reductase enzymes due to salinity treatment in sesame. The amount of superoxide dismutase, catalase and peroxidase increased in brassica napus under saline conditions. In rice, it was observed that the activity of superoxide dismutase, glutathione reductase, catalase and peroxidase antioxidant enzymes increased under salinity stress.

The activity of glutathione reductase, ascorbate peroxidase and superoxide dismutase antioxidants in the seedling stage on different brassica napus genotypes under salinity stress. They reported that in salinity stress of $200 \mathrm{mM} \mathrm{NaCl}$, antioxidant activity decreased

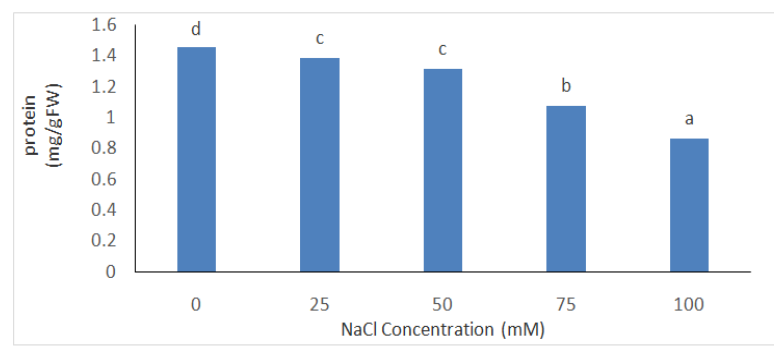

Figure 8. Effect of the interaction of salinity levels on physiological properties (protein).

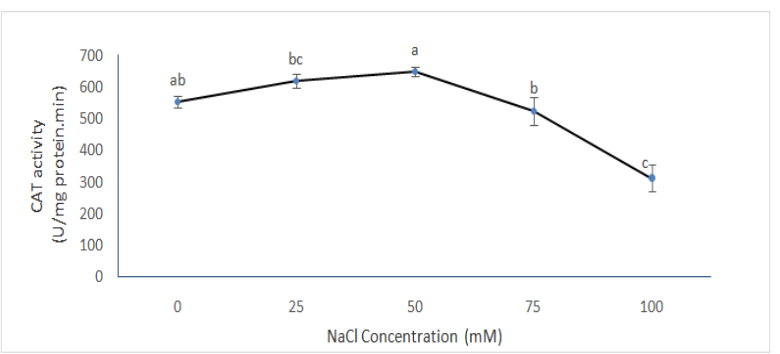

Figure 10. Effect of the interaction of salinity levels on physiological properties (catalase- CAT).

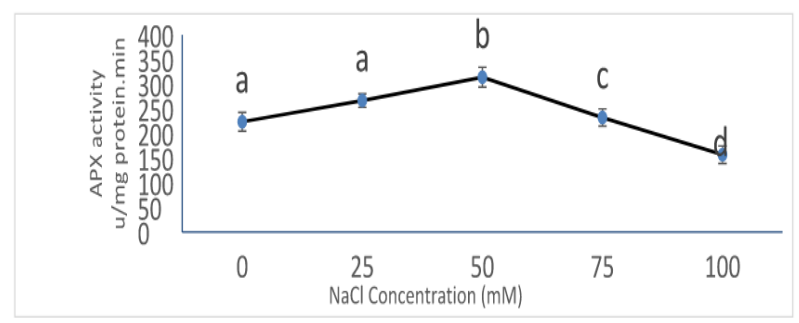

Figure 12. Effect of the interaction of salinity levels on physiological properties (APX).

because high salt concentration destroys the protein structure of enzymes (Shahbazi, 2015).

\subsection{The salinity effect on micro-tuberization}

No micro-tuber was formed at a salinity concentration of $100 \mathrm{mM} / \mathrm{l}$ and the number of microtuberization from the control group to higher levels had a downward trend and there was a significant difference between the medium of the control group and that of the other groups so that the extracted graph shows an inverse relationship (Figure 14). This research is similar to the reports of other researchers. An increase in salt minerals reduces the number of micro-tubers. Moreover, after potato meristem culture on MS medium, was verified that the bulking of micro-tubers, at the beginning, is caused by the alterations in the dimensions of the skin and brain parenchyma cells resulting from proliferative activity of apical meristem and also proliferative activity in the skin and brain parenchyma. In another report, they mentioned that salt minerals at high concentrations decrease the micro-tuber dry weight. The reduction in tuber weight with increased number of tubers is due to the decrease in each tuber's share of photosynthetic materials transferred from the leaves (Fakhimi, 2018). 


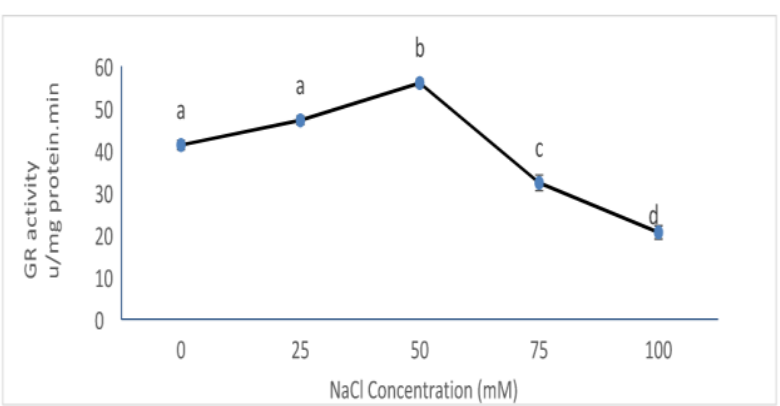

Figure 13. Effect of the interaction of salinity levels on physiological properties (GR).

\subsection{The salinity effect on tuber weight}

No micro-tuber was formed at a salinity concentration of $100 \mathrm{mM} / \mathrm{l}$ and the number of micro-tuberization from the control group to higher levels or concentrations of $100,75,50$ and $25 \mathrm{mM}$ had a downward trend and there was a significant difference between the medium of the control group and that of the other groups (Figure 15).

The results of the effect of different salinity levels on chlorophyll a, chlorophyll b, total chlorophyll and carotenoids in the study showed that potato cultivar Agria was subjected to salinity stress and its plant indicators decreased. The results of this research are in line with the findings of similar studies by other researchers on different plant cultivars. In response of self-growing potato species to salinity stress under in vitro culture, Daneshmand et al. (2011) reported that the amount of chlorophyll a, chlorophyll b, total chlorophyll and carotenoid decreased.

Arab Ahmadi et al. (2014) investigated the effect of salinity levels on the amount of chlorophyll a, chlorophyll $\mathrm{b}$, total chlorophyll and carotenoids of the safflower plant and reported that salinity levels reduce the amount of plant indicators. In similar studies, Ben Hamed et al. (2007) found that the amount of total chlorophyll and carotenoids in tomato decreased under salinity stress. Another reason is the decreased chlorophyll synthesis due to reduced absorption of ions such as $\mathrm{Fe}$ and $\mathrm{Mg}$ that play a fundamental role in the chloroplast structure and hence, by decreasing the absorption of these ions, chlorophyll synthesis decreases.

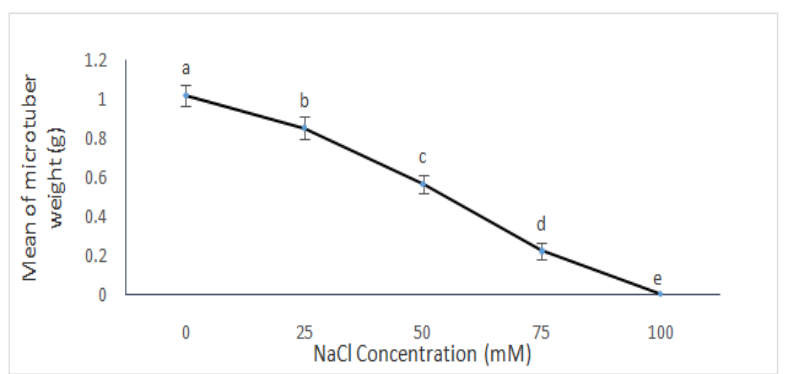

Figure 15. Effect of the interaction of salinity levels on tuber weight.

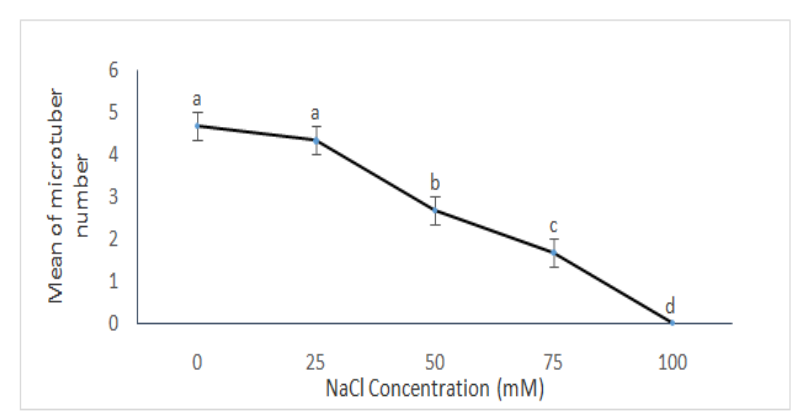

Figure 14. Effect of the interaction of salinity levels on microtuberization.

The results obtained in prunus dulcis plant indicated an inverse relationship between increased salinity and most of the photosynthetic pigment parameters and increased salinity at different levels decreased chlorophyll a, chlorophyll b and total chlorophyll (Dubey, 1994). In investigation of physiological responses to salinity and drought stress in flax plant, it has been reported that with increased salinity and drought of leaf soluble protein, catalase enzyme activity, total chlorophyll and carotenoid content decrease (Moeini and Kahrizi, 2003).

In evaluating the effect of salinity on physiological indices of kochia prostrata rangeland species, it was revealed that with increased salinity concentration up to $200 \mathrm{mM} \mathrm{NaCl}$, glycine, betatin, and soluble sugar content increased (Koca et al., 2007). Hung and Redman (1995) reported that due to the destruction of insoluble carbohydrates and their conversion to soluble carbohydrates during stress, the synthesis of soluble sugars from the non-photosynthetic pathway also increases. Another way to deal with salinity and drought stress is the synthesis of compatible and osmotic compounds. For example, we can refer to proline compounds, whose amount was measured in this study. An increase in proline content of potato due to $\mathrm{NaCl}$ stress at different levels (Figure 1-4) indicated that as salinity increases, its content also increases and there is a direct relationship between increased salinity and proline content.

Szabados et al. (2011) demonstrated proline efficiency under stress conditions, osmotic regulation, enzyme and membrane protection, free radical removal and energy and nitrogen storage for use during exposure to salinity stress. In addition, biochemical studies have shown that under salinity stress, some organic compounds (compatible solutions) accumulate in plants. These compounds do not interfere with biochemical processes. Among these compounds, one can refer to types of soluble sugars such as mannitol and sucrose, arabinose and nitrogen compounds (amino acid, proline and glycine betaine). Studies by other researchers in 2015 on Prunus dulcis displayed that there is a direct 
and positive relationship between increased salinity and proline content, and increased salinity at different levels increases proline (Fakhimi, 2018). Karimi and Assareh (2012), while examining the effect of salinity on physiological indicators of a rangeland species, reported that proline content increased as salinity increased up to $200 \mathrm{mM}$ Nacl.

Similar reports disclosed that as salinity increased, proline content increased and glycine betaine decreased (Khavarinejad and Chaparzadeh, 1998). Other researchers' reports on sensitive rice and Indian sesame cultivars under salinity stress showed increased malondialdehyde content. Further, the above researchers reported that MDA content in oat increased under salinity stress due to $\mathrm{H}_{2} \mathrm{O}_{2}$ accumulation, which is caused by the peroxidation of membrane lipids and compounds such as malondialdehyde, propanal, butanal, hexanal, heptanal and propanal dimethyl acetal. These have been used as indicators to measure the amount of membrane lipid peroxidation. In investigating the physiological responses to salinity and drought stress in flax plant, it was reported that with increasing salinity and drought, malondialdehyde has a significant increase compared to the control group (Moeini and Kahrizi, 2003).

Another way to deal with salinity and drought stress is hydrogen peroxide synthesis, whose amount has been measured in this research. Salinity stress causes oxidative stress and acts as a secondary stress (Mollassiotis et al., 2006). Oxidative stress occurs following a rapid increase in reactive oxygen species (ROS).

As a result, plants use different protective mechanisms to cope with stress. In investigating the amount of phenol measured in this study, it was determined that salinity stress has caused a significant increase in the amount of phenolic compounds so that it increased up to a salinity level of $50 \mathrm{mM}$ and then decreased in $75 \mathrm{mM}$ and in a salinity level of $100 \mathrm{mM}$, it reached its lowest level, which can be clearly seen in figures (1-7). Fakhimi (2018), in an in vitro experiment on potato cultivar Agria under salinity stress, reported that as the salinity level increased, total phenol content also increased and this increase was significantly different from the control group.

Abe et al. (1988) maintained that in salinity stress, phenolic compounds decrease and these compounds have been identified as major constituents of plants and many tasks have been assigned to them. Phenolic compounds are part of soluble substances of the cell that have a moderating effect during stress period. Besides, the accumulation of phenolic compounds in salt-tolerant plants is a strategy to inhibit the activity of active oxygen radicals and protect the membrane against salinity stress damage. Compounds such as coumarin, flavonoids, catechol and caffeic acid are considered as phenolic compounds.

Another biochemical process measured and examined in the study includes proteins. The results on Prunus dulcis showed that with increasing salinity, protein decreased (Dubey, 1994). It has been shown that under salinity stress, the amount of proteins in cassia plant increases, which is associated with increased synthesis of proteins such as HSP and LEAS. These proteins protect the plant against environmental stresses. These proteins produced under stress conditions act as chaperones and protect the enzymes and proteins in the cell. Argues that in general, salts have two incompatible effects on proteins: 1) The tendency to break electrostatic bonds; 2) increased hydrophobic interactions. As to the salinity effect on strawberries, it has been reported that the soluble protein of this plant increases at low salinity and decreases at high salinity. Another report on the salinity effect on plant proteins suggests that the production of new proteins in this plant has been induced under salinity stress (Movahhedi Dehnavi, 2017).

In investigating the effect of salinity stress on osmotic potential, Saeidipour (2015) reported the concentration of soluble sugars and proteins in different rice genotypes at the seedling stage. No stress was observed in any of the cultivars under treatment in the soluble protein concentration although in the salttolerant cultivar, unlike other cultivars, protein concentrations increased. Experiments from the results of this study (Figure 1-8) indicated that the results are consistent with recent research experiments. Since all creatures have a defense system to protect themselves, plants are no exception.

Although plants, unlike animals, do not have the ability to escape the biological or non-biological enemy because of lack of hands and feet, to confront biological and non-biological lethal factors, their defense systems are designed to resist and survive. Researchers believe that to reduce or overcome the oxidative damages caused by ROS, plants are equipped with a defense system. One of their defense systems is the activity of antioxidant enzymes such as, peroxidase, superoxide dismutase and catalase, glutathione reductase, guaiacol peroxidazole and ascorbate peroxidase. The role of peroxidase is to participate in the immune system of the cell and to detoxify the reactive oxygen species that deplete the oxygenated water produced by the stressor (Movahhedi Dehnavi, 2017).

The amount of SOD, CAT and APX increased in Brassica napus under saline conditions. In rice, it was observed that the activity of superoxide dismutase, glutathione reductase, catalase and peroxidase antioxidant enzymes increased under salinity stress (Movahhedi Dehnavi, 2017). 
Movahhedi Dehnavi (2017), in the investigation of physiological responses to salinity and drought stress in flax, reported that with increasing salinity and drought, catalase activity significantly increased compared to the control group. Sairam et al. (1998) conducted a study on the effect of salinity stress on the changes in the antioxidants of the leaf of two drought tolerant and semi-tolerant wheat genotypes and found that salinity, at all levels, has increased the activity of superoxide dismutase, glutathione reductase and catalase.

Darreki (2015) examined the effect of salinity stress on physiological properties and activity of chickpea antioxidant enzymes and concluded that different levels of salinity increased the antioxidant activity of chickpea. An increase from 1 to $7 \mathrm{dS} / \mathrm{m}^{2}$ increased catalase activity by $63.79 \%$ and at a salinity of $9 \mathrm{dS} / \mathrm{m}^{2}$, catalase activity decreased. Also, SOD activity increased up to 5 $\mathrm{dS} / \mathrm{m}^{2}$ salinity and remained unchanged at $7 \mathrm{dS} / \mathrm{m}^{2}$ salinity and decreased at $9 \mathrm{dS} / \mathrm{m}^{2}$ salinity. The highest salinity levels were observed at $75.95 \%$ increase in ascorbate peroxidase (APX) activity compared to the control group.

The activity of glutathione reductase, ascorbate peroxidase and superoxide dismutase antioxidants was studied in the seedling stage on different Brassica napus genotypes under salinity stress. Was reported that in salinity stress of $200 \mathrm{mM} \mathrm{NaCl}$, antioxidant activity decreased because high salt concentration destroys the protein structure of enzymes (Shahbazi, 2015).

Moreover, the amount of SOD, CAT and APX increased in Brassica napus under saline conditions (Movahhedi Dehnavi, 2017). Summary of the results of the researchers shows that increasing salinity generally increases the activity of all antioxidants and the results of this study are consistent with those of other researchers. This research reports that all antioxidants assayed increase up to $50 \mathrm{mM}$ and then have a downward trend at higher salinity levels.

Among all manufacturers, the amount of production and crop yield is very important, especially among the producers of livestock and agricultural products because any lethal factor can cause immense and irreparable damages to them and can destroy the result of one year's or one crop season's hard work of a producer and can also be economically detrimental to the households and threaten their families and put them on the brink of failure. In this study, another physiological characteristic assayed includes tuber weight and tuber number of the plant under different salinity levels.

Accordingly, at higher concentrations, both tuber weight and tuber number decreased sharply compared to the control group. From the results, Figures (14) and (15), it is inferred that the relationship between salinity levels with tuber number and tuber weight is an inverse relationship stated that increased salt minerals reduce the number of micro-tubers (Khatamsaz, 1998). Additionally, performed potato meristem culture on MS medium and announced that the bulking of microtubers, at the beginning, is caused by the alterations in the dimensions of the skin and brain parenchyma cells resulting from proliferative activity of apical meristem and also proliferative activity in the skin and brain parenchyma. In another report, they maintained that salt minerals at high concentrations decrease micro-tuber dry weight. The reduction in tuber weight with increased number of tubers is due to the decrease in each tuber's share of photosynthetic materials transferred from the leaves (Ebadi et al., 2011).

\section{Conclusions}

The Agria cultivar is among the semi-resistant varieties of potato species because salinity levels stimulate higher antioxidant activity, and increased antioxidant metabolites under salinity induction conditions indicate the plant's capacity to eliminate active oxygen species produced in the plant in order to maintain plant stability and survival.

The cultivar Agria has little flexibility against salinity and this flexibility is the result of the enzymes that have increased under salinity stress and thus have made this potato cultivar resistant to various levels of salinity up to about $50 \mathrm{mM}$. This suggests the activity of the enzyme surface measured at plant growth stages in salinity.

Thus, it is recommended that to more fully understand and evaluate the types of antioxidant metabolites in potato, more species be used in field and laboratory experiments and be measured and studied by students in plant physiology and agriculture and other related researchers in future studies. Also, the cultivars that have the highest increase in antioxidant metabolites and cause the plant's resistance to salinity should be promoted as the most resistant cultivar to salinity and other non-biological lethal factors in the region and other parts of the world that have similar conditions to our region.

\section{Bibliographic References}

Abe, K., Yuki, S., Kogure, K., 1988. Strong attenuation of ischemic and postischemic brain edema in rats by a novel free radical scavenger. Stroke, 19(4), 480-485.

Arab Ahmadi, H., Abaspour H., Gorbanli, M., 2014. The effect of salinity and ascorbate on seed germination percentage, growth parameters, proline and glycine betaien content in two cultivars of safflower (Carthamus Tinctorius L.). Journal of Plant Environmental Physiology, 9(1), 67- 76.

Ben Hamed, K., Castagna, A., Salem, E., Ranieri, A., Abdelly, C., 2007. Sea fennel (Crithmum maritimum L.) under salinity 
conditions: a comparison of leaf and root antioxidant responses. Plant Growth Regulation, 53(3), 185-194.

Chen, G.X., Asada, K., 1989. Ascorbate peroxidase in tea leaves: occurence of two isozymes and the differences in their enzymatic and molecular properties. Plant \& Cell Physiology, 30(7), 987-998.

Christie, P.J., Alfenito, M.R., Walbot, V., 1994. Impact of low-temperature stress on general phenylpropanoid and anthocyanin pathways: Enhancement of transcript abundance and anthocyanin pigmentation in maize seedlings. Planta, 194(4), 541-549.

Daneshmand, F., Arvin, M.J., Kalantari, K.M, 2011. Reponses of wild species of potato to salt stress under in vitro culture. Iranian Journal of Biology, 24(1), 65-78.

Darreki, S., 2015. The effect of salinity stress on physiological properties and activity of chickpea Azad cultivar antioxidant enzymes. Iranian Journal of Agricultural Research, 14(3), 470483.

Dubey, R.S., 1994. Protein synthesis by plants under stressful conditions, in: Pessaraki, M., (Ed.). Hand book of plant and crop stress. Marcel Dekker, New York, p. 277-299.

Ebadi, M., Majd, A., Fallahian, F., 2011. Evaluation of developmental-cellular process of potato plant in tissue culture, cell and semi-continuous and continuous bioreactors. Thesis Islamic Azad University, Science and Research Branch, Iran.

Fakhimi, R.H., 2018. In vitro study of the effect of salicylic acid on some growth and biochemical properties of potato cultivar Agria under salinity stress. Journal of Plant Environmental Physiology, 13(5), 1-12.

Gao, Z.F., Sagi, M., Lips, S.H., 1998. Carbohydrate metabolism in leaves and assimilate partitioning in fruits of tomato (Lycopersicon esculentum L.) as affected by salinity. Plant Science, 1(3), 149-159.

Hipskind, J., Wood, K., Nicholson, R.L., 1996. Localized stimulation of anthocyanin accumulation and delineation of pathogen ingress in maize genetically resistant to Bipolaris maydis Race O. Physiological and Molecular Plant Pathology, 49(4), 247-256

Hung, I., Redman, R.E., 1995. Solute adjustment to salinity and calcium supply in cultivated and wild barley. Journal of Plant Nutrition, 18(7), 1371-1389.

Karimi, G.H., Assareh, M.H., 2012. Effects of salinity stress on some physiological characteristics of kochia prostate. Iranian Journal of Range and Desert Research, 18(4), 537-546.

Khatamsaz, M., 1998. Solanaceae (No. 24), in: Assadi, M. et al. (Ed.). Flora of Iran. Research Institute of Forests and Rangelands, $114 \mathrm{p}$.
Khavarinejad, R.A., Chaparzadeh, N., 1998. The effects of $\mathrm{NaCl}$ and $\mathrm{CaCl}_{2}$ on photosynthesis and growth of alfalfa plants. Photosynthetica, 35, 461-466.

Khorshidi Benam, M.B., Rahimzadeh Khoii, F., Mirhadi, M.J., Nour-Mohamadi, G., 2002. Study of drought stress effects in different growth stages on potato cultivars. Iranian Journal of Crop Sciences, 4(1), 48-59.

Koca, H., Bor, M., Ozdemir, F., Turkan, I., 2007. The effect of salt stress on lipid peroxidation, antioxidative enzymes and proline content of sesame cultivars. Environmental and Experimental Botany, 60(3), 344-351.

Moeini, A., Kahrizi, H., 2003. Plant cultivation translation. Student Mobilization Organization, SAMT publisher, 66-69.

Mollassiotis, A.N., Sotiropoulos, T., Tanou, G., Kofidis, G., Diamantidis, G., Therios, I., 2006. Antioxidant and anatomical responses in shoot culture of the apple rootstock MM 106 Treated with $\mathrm{NaCl}, \mathrm{KCl}$, mannitiol or sorbitol. Biologia Plantarum, 50(3), 331-338.

Movahhedi Dehnavi, M., Niknam, N., Behzadi, Y., Mohtashami, R., Bagheri, R., 2017. Comparison of physiological responses of linseed (Linum usitatissimum L.) to drought and salt stress and salicylic acid foliar application. Iranian Journal of Plant Biology, 9(3), 39-62.

Munns, R., 2005. Genes and salt tolerance: Bringing them together. New Phytol, 167, 645-663.

Nakano, Y., Asada, K., 1981. Hydrogen peroxide is scavenged by ascorbate-specific peroxidase in spinach chloroplasts. Plant Cell Physiology, 22(5), 867-880.

Saeidipour, S., 2015. Salinity effects on osmotic potential, soluble proteins and carbohydrates concentration in rice (Oryza sativa) genotypes at seedling stage. Applied Field Crops Research (Pajouhesh \& Sazandegi), 109, 1-8.

Sairam, R.K., Deshmukh, P.S., Saxena, D.C., 1998. Role of antioxidant systems in wheat genotype tolerance to water stresses. Biologia Planta, 41(3), 387-394.

Shahbazi, P., 2015. The effect of salinity stress on antioxidant activity and seedling growth in Safflower (Carthamus tinctorius L.) genotypes, 7(1), 10-21.

Szabados L., Kovacs H., Zilberstein A., Bouchereau A., 2011. Plants in extreme environments: importance of protective compounds in stress tolerance. Advances in Botanical Research, 57, 105-150.

Zarghami, R., 2009. The effect of culture medium and used hormones on root formation and growth of single nodes from potato meristem culture. First Biotechnology Conference, Tehran, 34-55. 